\section{Music from \\ Czechoslovakia}

"ARTIA"

BENDA, J. A

16 Sonatas

BRIXI, F. X.

Concerto in F, Full Score . $22 / 6$

DUSIK, J. L.

Six Sonatas for Harp . . $8 / 6$

DVOŔÁK, A.

Sextet, op. 48. Pocket Score . 11/-

Sonata, op. 57 for Violin and Piano $11 / 6$

Symphony in D, op. 6o. Pocket Score

Piano Trio, op. 65. . . 21/-

From the Bohemian Forest, op. 68, Piano Duet . . 20/-

Quintet in A, op. 81. Pocket Score

Four Songs, op. 82.

Soprano or Tenor . . 7/-

, Alto or Baritone . . 7/-

Love Songs, op. 83 . . . $15 / 6$

Othello, op. 93, Full Score . 30/, Pocket Score . . 9/-

Suite, op. 98, Piano $\quad . \quad$. $7 / 6$

$\mathrm{FIBICH}, \mathrm{Z}$.

Piano Pieces, op. 44.

Books 2 and 4 . . each $3 / 6$

JANÁČEK, L.

The Diary of one who vanished.

Pocket Score

MYSLIVEČEK, J.

String Quartet. Score and parts 30/ROSSLER-ROSETTI

Nocturne in D minor. Parts . $\quad 7 / 6$

SMETANA, B.

2nd String Quartet in D minor.

Parts

$12 /-$

VRANICKY, P.

String Quartet in $\mathrm{B} b$, op. $15 \quad .11 / 6$
Music from Hungary

"KULTURA"

BARFARK/FARKAS

Three Lute Fantasias, Piano $\quad 3 / 6$

\section{DELIBES/DOHNANYI}

Waltzes from "Naila" and "Coppelia," Piano . . 9/-

DOHNANYI, E.

Ruralia Hungarica, op. $32 \mathrm{~A}$, Piano $11 /$

Ruralia Hungarica, op. ${ }_{32} \mathrm{C}$, Violin and Piano. . . $13 / 6$

Finger Exercises, Piano . . $\quad 7 / 6$

\section{RAJECZKY}

Melodiarium Hungariae Mediiaevi

Vol. I, Hymne et Sequentixe I15/-

\section{RÁNKI}

King Pomade's New Clothes.

Pocket Score . . . 15/.

STRAUSS, J.

Two Waltzes, Piano . . 9/-

SZERVÁNSZKY, E.

Flute Concerto. Pocket Score . 15/, Flute and Piano . . 15/-

Quintet for Wind Instruments.

Parts . . . . 21/6

Pocket Score. . . . $7 / 6$

VISKI, J.

Concerto for Cello and Piano . 18/-

VIVALDI

Siciliana for Violin and Piano . $3 / 6$

\title{
Selling Agents
}

\section{BODSEY \& HAWKES}




\section{INTERNATIONAL \\ CELEBRITY CONCERTS}

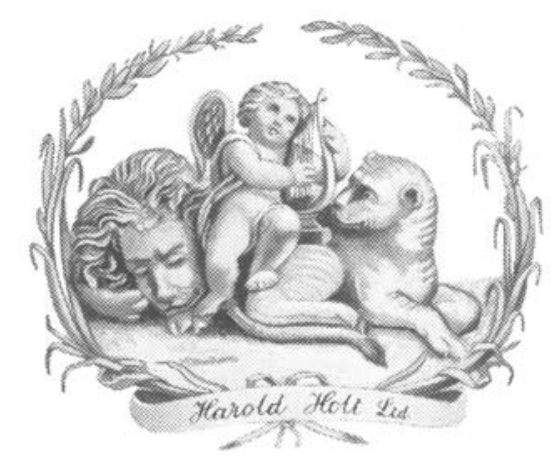

The Concert Hall Mark

of Quality in

Living Music

\section{DIRECTION HAROLD HOLT LTD}

